\title{
Elevation of Mycoplasma agalactiae subsp. bovis to Species Rank: Mycoplasma bovis (Hale et al.) comb. nov.
}

\author{
GERD ASKAA AND HENNING ERN $\emptyset$ \\ FAO/WHO Collaborating Centre for Animal Mycoplasmas, Institute of Medical Microbiology, University of \\ Aarhus, DK-8000 Aarhus C, Denmark
}

\begin{abstract}
Serological and deoxyribonucleic acid-deoxyribonucleic acid homology studies were performed with PG2 and Donetta, the type strains of Mycoplasma agalactiae subsp. agalactiae Wroblewski 1931 and Mycoplasma agalactiae subsp. bovis Hale et al. 1962, respectively. It is concluded that the two subspecies should rather be regarded as two different species. It is proposed, therefore, that $M$. agalactiae subsp. bovis be elevated to the rank of species. The species name is $M$. bovis (Hale et al.) comb. nov.
\end{abstract}

An organism causing bovine mastitis was isolated and tentatively classified as $\mathrm{Myco-}$ plasma agalactiae subsp. bovis by Hale et al. (10). The type strain of this proposed new taxon is Donetta (PG45) (6). Jain et al. (11) studied the serological relationships of several strains associated with mastitis, isolated at different laboratories in the United States. They concluded that some strains, including Donetta (synonymous with "Connecticut"), California 01 , and Widanka, formed a homogenous and distinct group as determined by double immunodiffusion and growth inhibition tests. Jain et al. (11) did not find the name $M$. agalactiae subsp. bovis appropriate because of the lack of serological comparison with the type strain (PG2) of $M$. agalactiae Wroblewski 1931 (22) and therefore suggested the alternative name $M$. bovimastitidis. However, these authors did not present sufficient data to determine whether this group of mycoplasmas deserved the rank of a distinct species, rather than being classified as a subspecies of $M$. agalactiae. The necessity of carrying out comparative studies was emphasized by Leach (13) and has been discussed repeatedly by the Subcommittee on the Taxonomy of Mycoplasmatales $(18,20,21)$.

Serological comparisons between $M$. agalactiae and the group in question were carried out by Al-Aubaidi and Fabricant using metabolism inhibition tests (1) and a direct immunofluorescence technique (2). They did not find any crossreactions between $M$. agalactiae and their serotype $F$ (synonymous with $M$. agalactiae subsp. bovis/M. bovimastitidis), which included the Donetta strain. Leach (14) obtained measurable metabolism inhibition titers when testing two
$M$. agalactiae strains with antisera against three strains, including strains Widanka and Donetta, of his serogroup 5. The titers varied and were usually less than 0.01 of those obtained with the homologous strain. Only oneway cross-reactions were observed. On the basis of these results, Leach (14) recommended that $M$. agalactiae subsp. bovis be conserved as the valid name for these organisms and that the name $M$. bovimastitidis be rejected. Statements in support of this view were given by Ernø et al. (8) and Ernø and Jurmanová (7).

The electrophoretic patterns of cell proteins of PG2 and Donetta were studied by Razin (15). Although the patterns "differed in several bands," it was concluded that the similarities observed were in favor of the inclusion of the two strains in one species. Ernø and Stipkovits (9), in an investigation of 17 type or reference strains of bovine and ovine sources, did not find that electrophoretic studies allowed definite conclusions regarding the taxonomic status of PG2 and Donetta.

In the present study, the type strains PG2 and Donetta were compared serologically by indirect epi-immunofluorescence, metabolism inhibition, and growth inhibition tests as described by Rosendal and Black (16), Ernø et al. (8) and Ern $\emptyset$ and Jurmanová (7), respectively.

Furthermore, PG2 and Donetta were compared by deoxyribonucleic acid-deoxyribonucleic acid (DNA-DNA) hybridization experiments. The type strain (PG11) of $M$. bovigenitalium was included as a control because of its biochemical similarity to PG2 and Donetta. (The strains were obtained from D. G. ff. Edward, Public Health Laboratory, Dulwich 
Hospital, East Dulwich Grove, London SE1W 8RH, England.) DNA was isolated as described previously (3). Labeled DNA was extracted from organisms grown in broth containing 0.5 to $1.0 \mu \mathrm{Ci}$ of $\left[{ }^{3} \mathrm{H}\right]$ thymidine per $\mathrm{ml}$. The DNADNA hybridization method was the membrane filter technique of Denhardt (5). Direct-annealing experiments, as well as competition experiments, were carried out with $10 \mu \mathrm{g}$ of membrane-bound unlabeled DNA, 0.1 to $1.0 \mu \mathrm{g}$ of ${ }^{3} \mathrm{H}$-labeled DNA and, for competition, $150 \mu \mathrm{g}$ of unlabeled DNA.

The results of the serological comparisons are presented in Table 1. It can be seen that strains PG2 and Donetta are clearly distinct by metabolism inhibition, growth inhibition, and indirect immunofluorescence tests.

Table 2 shows the results of the hybridization experiments with strains PG2, Donetta, and

TABLE 1. Antigenic relationship of the type strains PG2 and Donetta

\begin{tabular}{l|r|c|c|r|c|c}
\hline \multirow{4}{*}{ Strain } & \multicolumn{4}{|c|}{ Antiserum to: } \\
\cline { 2 - 7 } & \multicolumn{3}{|c|}{ PG2 } & \multicolumn{3}{|c}{ Donetta } \\
\cline { 2 - 7 } & MI & $\begin{array}{c}\text { GI } \\
(\mathrm{mm})\end{array}$ & IMF & MI & $\begin{array}{c}\text { GI } \\
(\mathrm{mm})\end{array}$ & IMF \\
\hline PG2 & 12,800 & 4 & + & 16 & 0 & - \\
Donetta & 16 & 0 & - & 8,000 & 5 & + \\
\hline
\end{tabular}

${ }^{a}$ MI, Metabolism inhibition; GI, growth inhibition; IMF, indirect immunofluorescence.

TABLE 2. DNA-DNA hybridization of $M$. agalactiae subsp. agalactiae, $M$. agalactiae subsp. bovis, and $M$. bovigenitalium ${ }^{\prime \prime}$

\begin{tabular}{l|c|c|c}
\hline \multirow{2}{*}{$\begin{array}{c}{ }^{3} \text { H-labeled } \\
\text { DNA from: }\end{array}$} & \multicolumn{3}{|c}{ Hybridization (\%) } \\
\cline { 2 - 4 } & $\begin{array}{c}\text { M. agalactiae } \\
\text { subs. agalac- } \\
\text { tiae } \\
\text { (PG2) }\end{array}$ & $\begin{array}{c}\text { M. agalactiae } \\
\text { subsp. bovis } \\
\text { (Donetta) }\end{array}$ & $\begin{array}{c}\text { M. bovigeni- } \\
\text { talium } \\
\text { (PG11) }\end{array}$ \\
\hline PG2 & $100(3,543)^{b}$ & $38(1,331)$ & $14(496)$ \\
Donetta & $40(3,088)$ & $100(7,785)$ & $5(394)$ \\
\hline
\end{tabular}

"In the homologous reaction, 32 and $20 \%$, respectively, of the labeled DNA were bound, whereas the unspecific binding to blank filters was 1.6 and $0.4 \%$, respectively.

${ }^{b}$ The numbers in parentheses show the actual measured counts per minute.
PG11. The homology values between PG2 and Donetta are 38 and $40 \%$, respectively, whereas 14 and 5\% homologies were found between these organisms and PG11. The results of the competition experiments between strains PG2 and Donetta are given in Table 3 . According to these data, the homology values are 38 and $35 \%$.

The Subcommittee (17-19) has supported the general view that the separation of a group of organisms into two or more species should be based on a variety of distinctive properties and that particular emphasis should be put on the results of growth and metabolism inhibition tests and gel electrophoresis and nucleic acid hybridization studies (18). In 1974, the Subcommittee (20) expressed the view that the data presented by Leach (14) in support of recognizing the Donetta-like strains as a subspecies of $M$. agalactiae were insufficient and, hence, would await the results of additional studies based on gel electrophoresis and nucleic acid hybridization techniques before it made recommendation on this issue. The Subcommittee later recommended (21) that the studies be extended to include California 01 as the reference strain of $M$. bovimastitidis (11). To involve in the studies a special reference strain for $M$. bovimastitidis, however, does seem to blur the issue, which is simply a question of classification and nomenclature of a certain group of mycoplasmas, as pointed out by Jain et al. (11). The serological identity of different strains within this group has never been disputed $(1,2$, 14), notably not by Jain et al. (11), who, as mentioned previously, also compared strains Donetta and California 01.

The relative genetic homologies among organisms of different taxa have been studied most extensively for bacteria, in which the degree of relatedness at the subspecies level was proposed by Johnson (12) to be 60 to $70 \%$. This proposal is in agreement with that of Brenner (4), who in most cases found a relatedness of $70 \%$ or more between strains of species of the family Enterobacteriaceae.

In summary, it appears that strains PG2 and Donetta have essentially the same biochemical

TABLE 3. Competition experiments between DNA from $M$. agalactiae subsp. agalactiae (PG2) and $M$. agalactiae subsp. bovis (Donetta)

\begin{tabular}{c|c|c|c}
\hline Homologous system & Homologous competitor DNA & Heterologous competitor DNA & Homology $^{a}(\%)$ \\
\hline PG2 $(14.4)^{b}$ & PG2 (4.0) & Donetta (10.5) & 38 \\
Donetta (19.2) & Donetta (3.8) & PG2 (13.8) & 35 \\
\hline
\end{tabular}

\footnotetext{
"Percent homology = I (percent binding in homologous system - percent binding in heterologous competitor system)/(percent binding in homologous system - percent binding in homologous competitor system)] $\times 100$.
}

${ }^{b}$ The values in parentheses are the percentages of the input radioactivity bound in the reactions. 
and biological characters (9). They do have common antigens, as shown by double immunodiffusion (7), but cross-reactions have never been demonstrated by growth inhibition and immunofluorescence, and only weak or oneway cross-reactions have ever been found by metabolism inhibition. Considering the species concept of mycoplasmas in general and the homology levels cited above, it would not seem justifiable to classify the Donetta-like strains as a subspecies of $M$. agalactiae but rather as a separate species, with the type strain Donetta (PG45). The name for this new species is $M$. bovis (Hale et al.) comb. nov.

\section{ACKNOWLEDGMENTS}

This work was supported by grant $512-4243$ from the Danish Medical Research Council.

\section{REPRINT REQUESTS}

Address reprints requests to: Gerd Askaa, Institute of Medical Microbiology, The Bartholin Building, University of Aarhus, DK-8000 Aarhus C, Denmark.

\section{LITERATURE CITED}

1. Al-Aubaidi, J. M., and J. Fabricant. 1971. Characterization and classification of bovine Mycoplasma. Cornell Vet. 61:490-518.

2. Al-Aubaidi, J. M., and J. Fabricant. 1971. The practical application of immunofluorescence (agar bloc technic) for the identification of Mycoplasma. Cornell Vet. 61:519-542.

3. Askaa, G., C. Christiansen, and H. Ernø. 1973. Bovine mycoplasmas: genome size and base composition of DNA. J. Gen. Microbiol. 75:283-286.

4. Brenner, D. J. 1973. Deoxyribonucleic acid reassociation in the taxonomy of enteric bacteria. Int. J. Syst. Bacteriol. 23:298-307.

5. Denhardt, D. T. 1966. A membrane-filter technique for the detection of complementary DNA. Biochem. Biophys. Res. Commun. 23:641-646.

6. Edward, D. G. ff., and E. A. Freundt. 1973. Type strains of species of the order Mycoplasmatales, including designation of neotypes for Mycoplasma mycoides subsp. mycoides, Mycoplasma agalactiae subsp. agalactiae, and Mycoplasma arthritidis. Int. J. Syst. Bacteriol. 23:55-61.
7. Ernø, H., and K. Jurmanová. 1973. Bovine mycoplasmas: serological studies by double immunodiffusion, growth precipitation and growth inhibition. Acta Vet. Scand. 14:524-537.

8. Ernø, H., K. Jurmanová, and R. H. Leach. 1973. Bovine mycoplasmas: a serological study by the metabolic inhibition test. Acta Vet. Scand. 14:511-523.

9. Ernø, H., and L. Stipkovits. 1973. Bovine mycoplasmas: cultural and biochemical studies. II. Acta Vet. Scand. 14:450-463.

10. Hale, H. H., C. F. Helmboldt, W. N. Plastridge, and E. F. Stula. 1962. Bovine mastitis caused by a $\mathrm{Myco-}$ plasma species. Cornell Vet. 52:582-591.

11. Jain, N. C., D. E. Jasper, and J. D. Dellinger. 1967. Cultural characters and serological relationships of some mycoplasmas isolated from bovine sources. J. Gen. Microbiol. 49:401-410.

12. Johnson, J. L. 1973. Use of nucleic-acid homologies in the taxonomy of anaerobic bacteria. Int. J. Syst. Bacteriol. 23:308-315.

13. Leach, R. H. 1967. Comparative studies of mycoplasma of bovine origin. Ann. N.Y. Acad. Sci. 143:305-316.

14. Leach, R. H. 1973. Further studies on classification of bovine strains of Mycoplasmatales, with proposals for new species, Acholeplasma modicum and $M y c o-$ plasma alkalescens. J. Gen. Microbiol. 75:135-153.

15. Razin, S. 1968. Mycoplasma taxonomy studied by electrophoresis of cell proteins. J. Bacteriol. 96:687-694.

16. Rosendal, S., and F. T. Black. 1972. Direct and indirect immunofluorescence of unfixed and fixed mycoplasma colonies. Acta Pathol. Microbiol. Scand. Sect. B 80:615-622.

17. Subcommittee on the Taxonomy of the Mycoplasmata. 1967. Minutes of the first meeting. Int. J. Syst. Bacteriol. 17:105-109.

18. Subcommittee on the Taxonomy of Mycoplasmatales. 1971. Minutes of the Meeting, 10 August 1970. Int. J. Syst. Bacteriol, 21:151-153.

19. Subcommittee on the Taxonomy of Mycoplasmatales. 1972. Proposal for minimal standards for descriptions of new species of the order Mycoplasmatales. Int. J. Syst. Bacteriol. 22:184-188.

20. Subcommittee on the Taxonomy of Mycoplasmatales. 1974. Minutes of the Meeting, 5 and 6 September 1973. Int. J. Syst. Bacteriol. 24:390-392.

21. Subcommittee on the Taxonomy of Mycoplasmatales. 1975. Minutes of the Interim Meeting, 18 September 1974. Int. J. Syst. Bacteriol. 25:237-239.

22. Wroblewski, W. 1931. Morphologie et cycle évolutif des microbes de la péripneumonie des bovides et de l'agalaxie contagieuse des chèvres et des moutons. Ann. Inst. Pasteur Paris 47:94-115. 